\title{
Gender Bias and Social Justice
}

\author{
Mahadevappa. T.C \\ Associate Professor Of Political Science, Plot No. 22,Poojya Coloney,Near Bhavani Temple,Kusnoor Road \\ ,Gulbarga-585106. (Karnatka)
}

\section{Introduction}

When writing about gender bias, it is important to define and understand the term Gender is defined by the American Heritage Dictionary of "Classification of Sex", and bias is defined as "Preference or prejudice". Thus gender bias is separation of gender in a way which prefers our sex over the other.

Gender bias is one of the major issue in many countries and largely in India. This practice is as old as society. A great political thinker Aristotle himself discriminated by stating "Women not have strength as men and they are not eligible for outside work. Until 1875 women were not legally defined as persons in The United State (U.S.) and they are denied by visiting until early $20^{\text {th }}$ century. Today also religion not allowed women to lead free life. Muslim women put burkhas on their face. Hindu religion also put many restriction on women. All this fad indicates that how women were faced discrimination since the early age.

The practice of gender discrimination is considered as a social injustice. Now the time of change the attitude of men towards women. Today world became a global village and every one connected with the every part of the world. This can make change the attitude of men through the transformative of knowledge which leads to social justice.

This report mainly aims to find the facts and nature of the widespread discrimination universally practiced called as gender inequality.

It is also accepted that unless the world female population is not in a position to practically enjoy the equal social opportunity no social change, economic gain or political authority can lead to peaceful development of human society. Women are considered as a decisive force of social change and social development.

Gender bias is one of the major social problem in developing countries like India. It is as old as society and existed in present modern democratic world also. It led to paralyzed the society because one sex of the society discriminated by other sex. This social problem largely neglected in the period of kingship. Now the period of democratic so every one's rights have to protected in this form government.

So it is necessary to find the new solution and suggestions for this problem to making new policies. Present study provides many findings solutions and suggestions for the society and also

\section{Social Justice And Gender Bias}

Gender inequality cuts across all other dimension of inequalities, viz., economic, religious, regional, and national, of class, creed, colour and so on, in all societies. Hence, all activities for social justice are futile if gender inequality persists social justice are futile if gender inequality persists. It is interesting to note that the equal rights amendment proposed to the United States constitution was defeated by well organized and well financed opposite of corporate interests not in favour of government compelling then to pay and promote their women employees on equal bases of men.

John Stuart Mill, in his essay on the subjection of women, has optly pointed out that the emancipation or debasement of women is on the whole the surest test and the most correct measures of the civilization of a people or an age. Still the most pervasive and persistently followed discriminations in the one habitually and traditionally practiced by men against women folk. It is often sarcastically commented that there are only two castes in the world - the male and the female.

Gender inequality is often defended by men on the basis of nature, which they say conventionally allocates certain predetermined roles like child care, cooking housekeeping and the like to women: and political activity, paid employment, higher education, social leadership and the like to men. All religions have added weight to their authority for this earthly injustice with heavily sanction. This structure belief and practice caused untold harm to civilizations over time. Contemporary world is also for away from a sincere effort to remove the obstacle.

Initial efforts towards women's emancipation were directed to political field and aimed at obtaining franchise. For this the western women had to wage a long battle, just to discover that though essential, it was but the beginning. In most of the states, which became independent around the middle of the $20^{\text {th }}$ century, women 
obtained franchise just by the stroke of a pen, which once wrote adult franchise at the base of their democratic constitutions.

In India, the persistent high level of gender inequality assuming very subtle forms is much more astonishing and shocking. Development still tends to be defined in economic terms. Only, because starring halfback, homeless, people easily catch the eye and pose emotional material to journalists.

However, a woman girded to the household jobs, a girl given lower quality of food than the boy in the family, deprived of educational facility and better health care when it comes to choice almost always held responsible for a sex scandal, or psychologically tortured in the family and society, are the issues that go unnoticed. They still have wider negative influences on overall development process.

More serious is the modern medical technology has made it possible for parents all over India to abort a female foetus and go unnoticed. Instead of abolishing practice it has assumed dimensions beyond imagination. Lower social status is attached to a woman not having a son. Derogatory terms like "Nipatrika" are used for a woman not having a male child and not for a man of similar status. A male child is the "Kuldeepak" legend of the class.

Another serious issue is the "Fertility pattern" almost focusing women to produce children frequently. Consequently, they have to face not only frequent risks to their own survival but also ill health and lack of freedom to do other works of their choice.

It is also interesting to note that nearly 80 percent of family planning operations are undergone by females and almost low percent of medicinal precautions are their responsibility.

\section{Conclusions:}

The gender gap and gender bias in society are complicated issue. Gender bias in the world has its origins in numerous places and it is reinforced in just as many ways equal accessibility for girls can only come when parents, schools, administrators, manufactures, leaders, policy makers, judiciary work together for equal makers, judiciary work together for equal accessibility. Parents need to participate both in the house and school settings to ensure their girls are literate. Schools through the administration and teachers must actively encourage striation and teachers must actively encourage young girls interest in education. All these efforts together can help female practice portion in all effects of social life.

Presently the government trying to lowering the gender bias in society by making laws. Female are getting reservations in local bodies. Nearly $50 \%$ but this is not only salaries for gender bias. This problem can be solved through the change of mind of men living in society.

Women's problems cannot be solved by laws imposed by the state. The attitude and thinking have to change. No law can possibly say that a man has to treat his wife this way or that. It is conscience that has govern one, not laws.

Inspite of women enlarged in also aspect of administration, employment and education, the gender bias still exist in many place.

\section{Suggestions:}

You can help pull down the barriers that keep girls from attending school and begin to bring change for women in developing countries. The most direct way is by easing the financial need that forces families to take their children out of school in the first place.

Dozens of international organizations are working to improve the livelihood of impoverished people. By building infrastructure and providing aid, vocational training, and education programs, they give families in developing countries resources to create healthy and stable lives. That takes the burden of mere survival off young women and gives them the time to get an education. With practical help and encouragement, girls are more likely to enroll and stay in school.

UNICEF is encouraging all international organizations to come up with strategies for girls' education as part of their initial development plans. It has also started a movement to monitor school materials, facilities, and teachers to ensure that girls get a quality education that promotes appropriate perceptions of women, and those female students are given the same privileges as male students. All UNICFF and other reputable organizations need now are the resources to fund their efforts.

You can help begin to change the lives of women around the world by making a financial gift or raising awareness about girls in the developing world today. Children In Need offers internships and volunteer opportunities to people who want to help raise awareness of the issues that impact children. You can support Amnesty International, UNICEF, UNIFEM and value based education might also solve the problems of gender bias. Education will make these women think rationally and see things in the right perspective. 


\section{Bibliography}

[1] Bailey, S (1992) How Schools Shortchange Girls: The AAUW Report. New York, NY: Marlowe \& Company

[2] Jones, K., Evans, C., Byrd, R, Campbell, K. (2000) Gender equity training and teaching behavior Journal of Instructional psychology, 27 (3), 173 178.

[3] Klein, S. (1985) Handbook for Achieving Sex Equity Through Education. Baltimore, MD: The Johns Hopkins University Press.

[4] Marshall, C.S \& Reihartz, J. (1997) Gender issues in the classroom. Clearinghouse, 70 (6), 333-338.

[5] McCormick, P. (1995) Are girls taught to fail? U.S Catholic, 60, (2), 38-42.

[6] Mulrine, A (2001) Are Boys the Weaker Sex? U.S. News \& World Report, 131 (4), 40-48.

[7] O’Neill, T. (2000) Boys' problems don't matter Report! Newsmagazine (National Edition), 27 (15), 54-56

[8] Orenstein, P (1994) Schoolgirls: Young Women, Self-Esteem and the Confidence Gap. New York, NY: Doubleday.

[9] Reay, D. (2001) 'Spice girls', 'Nice Girls', 'Girlies', and 'Tomboys"; gender discourses. Girls' cultures and femininities in the primary classroom Gender and Education, 13 (2), 153-167.

[10] Sadker, D., Sadker, M. (1994) Failing at Fairness: How Our Schools Cheat Girls. Toronto, ON: Simon \& Schuster In. 